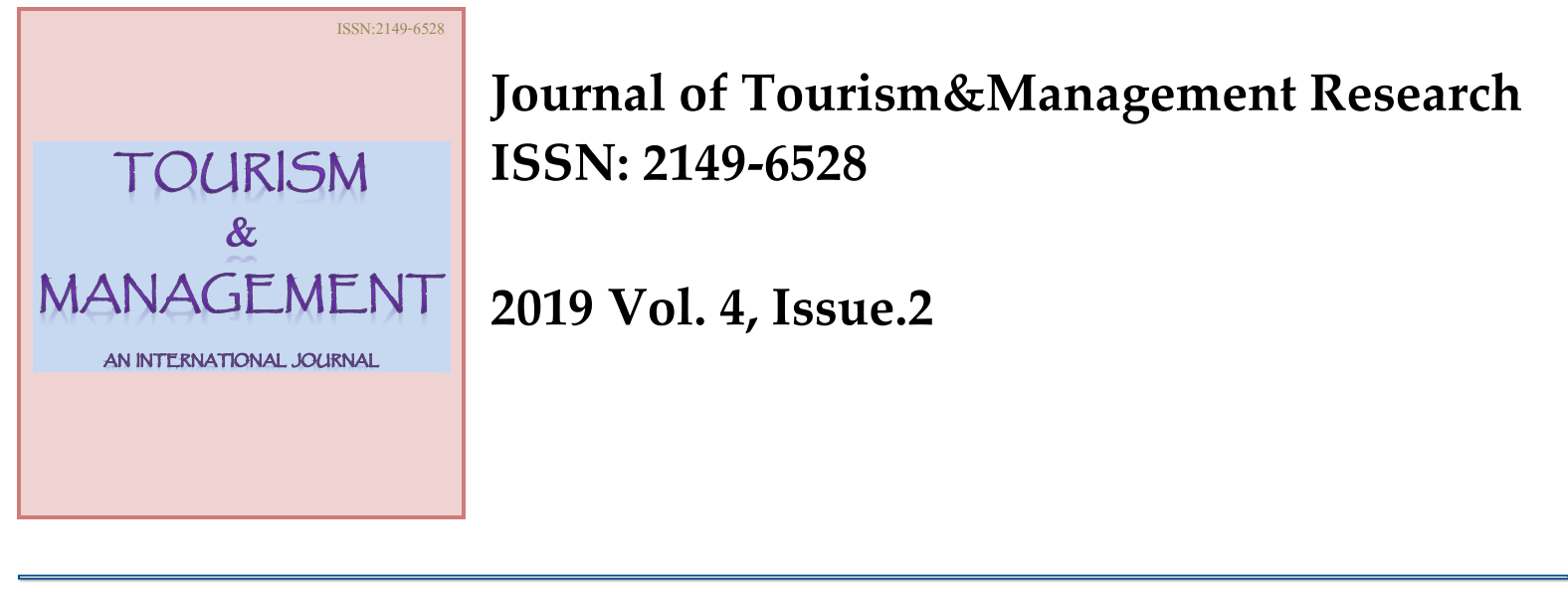

\title{
Urban Tourist Motivations in the City of Porto
}

\begin{abstract}
Porto is one of the fastest growing European tourist destinations that has experienced exponential growth in the demand for city-break tourists. Despite the growing importance of Porto as a tourist destination in the European and national context, there isn't still a systematic study that identifies and explores the pull factors that characterize the behaviour of tourists that visit the city of Porto. This study through the use of surveys conducted in the historic centre of Porto, and adopting the Analytical Hierarchy Process method, allows in a nonintrusive way to identify and prioritize those pull factors. The results of this study allowed identifying the hedonic consumption dimension, which includes both cultural motive and gastronomy variables, as the determining factor in the choice of tourists representing more than $50 \%$ of the tourist motivations. The results of this study are relevant for tourism professionals that intend to offer authentic experiences that simultaneously explore the unique cultural and gastronomic characteristics of the city of Porto.
\end{abstract}

Keywords: Tourist motivation, Pull factors, Porto, Destination choice, Decision making, Analytical hierarchy process.

JEL Classifications: L83, C44, D91

Submitted: 19/03/2019; Accepted:16/06/2019

Fernando Almeida, Professor. (Corresponding Author). University of Porto \& INESC TEC, Faculty of Engineering, Department of Informatics, Porto, Portugal. Tel: +351 225081400.

Email: almd@fe.up.pt

Oscar Silva, Professor. Higher Polytechnic Institute of Gaya, School of Science and Technology, ISPGaya, V.N.Gaia, Portugal. Tel:+351 223745730.

Email: osilva@ispgaya.pt

Nelson Amoêdo, Professor. Higher Polytechnic Institute of Gaya, School of Science and Technology, ISPGaya, V.N.Gaia, Portugal. Tel:+351 223745730.

Email: nma@ispgaya.pt 


\section{Introduction}

The success of a tourist destination depends on its ability to meet the needs and preferences of tourists. Some of these needs are globally identified in the literature, such as the looking for new experiences and knowledge, looking for rest and relaxation, searching for leisure activities, among others (Simková and Holzner, 2014; Wong et al., 2013). According to Mahika (2011), tourists are also moved by the desire to meet new places, people, cultivate new friendships or strengthen personal relationships.

In this sense, the motivation that is associated with a journey depends on the needs and desires of each individual, and these needs and desires vary at each stage of our life. According to the Push and Pull theory presented by Dann (1977), push factors are the elements that lead tourists to travel, regardless of the destination they choose; while pull is an external force consisting of the particularities and attributes of destinations, which influences the visitor and determines his choice.

In 2016, Portugal won 24 awards and a lot of tourist enterprises won awards, with Turismo de Portugal considered the deemed Europe's Leading Tourist Board. Also, according to the World Economic Forum, in 2016 Portugal was the 14th most competitive tourist destination of 136 countries (WEF, 2017), and the number of international tourist arrivals was around 11,423,000 (United Nations World Tourism Organization, 2017), it accounted for 6.4\% of Gross Domestic Product (GDP), with direct employment in tourism being about $8.1 \%$ of total employment. In their last edition in 2017, Portugal was singled out as the World's Leading Destination and awarded several other distinctions: Europe's Leading Destination, and Europe's Leading Beach Destination.

The destination Porto and North of Portugal, characterized by a multiproduct offering, targeted at different market segments, in line with the National Strategic Plan for Tourism (Ministério da Economia e da Inovação, 2007) and the Action Plan for Tourism Development in Northern Portugal (Comissão de Coordenação e Desenvolvimento Regional do NorteCCDRN, 2011) as regards the strategic guidelines relating to tourism products and differentiating attributes, it was decided to develop the following segments: (i) urban tourism; (ii) city breaks; (iii) business tourism; (iv) cultural tourism, events, scientific tourism, food \& wine, touring and cultural landscape; (v) natural tourism, health and wellness; (vi) nature tourism; and (vii) religious tourism.

Despite the growing importance of the city of Porto as a tourist destination in the European and national context, there isn't still any study that systematically identifies and analyzes the pull factors that are relevant for the choice of tourists visiting the city of Porto. In this sense, this study applies the Analytic Hierarchy Process (AHP) method to identify and prioritize those pull factors. The results of this study provide relevant information to serve as a basis for the decisions of tourism professionals, namely in the development of their strategies for promotion, communication, and segmentation.

The manuscript is organized as follows: initially, a review of the literature on push-pull theory is carried out and the main urban travel motivations are explored. Then, the methodology is presented in which the structure of the research of these studies and the employed methods are presented. After that, the results of this study are explored and discussed considering the context of the city of Porto and the existing literature in this field. Finally, the conclusions of the work are drawn and some suggestions for future work are given.

\section{Literature Review}

\subsection{Push-Pull Theory}

People decide to travel for different reasons and different motives, perceived as forces that reduce a state of tension refers that this state rises to a need that stimulates an attitude or 
behaviour. Crompton (1979) and Fodness (1994) identify psychological or social motives (push motifs) that support the desire to travel. According to Dann (1977), it is internal forces that motivate or create the desire of the individual to satisfy a need to travel. Fakeye and Crompton, cited by Cunha (2012) define seven motivational domains in the group of push factors:

1. Novelty (the desire for new and different experiences);

2. Socialization (the desire for group interaction);

3. Prestige / Status (the desire for reputation in the eyes of others);

4. Rest and Relaxation (desire to refresh mentally and psychologically and to subtract from the pressure of the day-to-day);

5. Value of Intellectual Enrichment;

6. Reinforcement and Search for a more intense family relationship;

7. Regression (desire to rediscover past behaviour reminiscent).

According to the same author, the pull factors are those that affect opinion regarding the place to visit and are attributes of the destination. On the other hand, the attributes of the destination that reinforce the internal push factors, such as beaches, fun, natural and cultural attractions, etc. are those that affect the opinion regarding the place to visit and are related to the attributes of the destination.

The study of motivation based on the interaction of push and pull factors is one of the most used models in tourism and due to its simplicity is adopted by several studies to explain the motivations of tourists (Jeong, 2014; Nikjoo and Ketabi, 2015; Phau et al., 2013). Push factors are related to the entire cognitive process, namely to the internal motivations of an individual and arise from intangible or intrinsic desires of an individual (Baloglu and Uysal, 1996). According to Kim et al. (2003), push factors are defined as motivational factors or needs that arise due to an imbalance or tension in the motivational system. These factors tend to explain the reasons why people choose one destination over another and characterize the demand of the tourism market, namely which is the type of most sought after experiences and which type of activities arouse more interest in the individual. Kim et al. (2003) summarize the seven push factors most commonly found in the tourism area: (i) novelty; (ii) escape from the daily environment; (iii) social interaction; (iv) prestige; (v) family interaction; (vi) appreciation of natural resources and health; and (vii) adventure and friendship building.

On the other hand, pull factors have been characterized as those that influence when, where and how people travel. These factors act as external forces, which manifest themselves through attributes of the destination itself, namely its attractive component, the surrounding physical environments and people's expectations of a given destination (Kim et al., 2003). According to Lubbe (2003), both tangible and intangible resources are included in pull factors. Pull factors have proven to be important in the process of choosing a tourist destination, and according to Prayag and Ryan (2011) the reasons associated with these types of attraction factors may vary according to demographic characteristics.

Motivation is necessarily a multidimensional factor, and given its complexity of construction, the application of models of push and pull motivations has been approached in different ways. Authors such as Dann (1977) and Kesnosky (2002) support a separate and uncorrelated analysis of these two dimensions. On the other hand, Kim et al. (2003) advocate a possible interaction between push \& pull factors, and propose a related construction of these factors. Despite this opposite view, it is generally considered that push and pull factors occur at separate moments of time, thus constituting two separate decisions even if they are interrelated. In this sense, Dunn (2009) argues that push factors precede pull factors at the time of decision making by the individual. Therefore, the internal forces drive people to travel and then the external forces of the destinations attract them in the choice of a particular destination. 


\subsection{Urban Travel Motivation}

The existing studies in the field of urban travel motivation are quite extensive and comprehensive. In general, each study in this area seeks to thoroughly analyze the impact of one of the pull factors or to jointly explore several factors and assess their relative importance.

The city of Porto is the 2nd largest city in Portugal and is located in the northern region of Portugal. The city presents a great cultural diversity, namely through its museums, churches and cultural spaces of high tourist interest. Furthermore, it was pointed European Capital of Culture in 2001, and the same distinction was obtained by the city of Guimarães (another northern Portuguese city) in 2012. Porto is located on the banks of the River Douro and its historic centre was added to United Nations Educational, Scientific and Cultural Organization's (UNESCO) representative World Heritage List in 1996 (Correia, 2018; Remoaldo et al., 2014; UNESCO, 2014). This distinction contributed significantly to the dissemination of the city of Porto as one of the main tourist destinations in Europe.

Gastronomy and wines are a touristic factor that works as a factor to capture and diversify the tourist offer (Sormaz et al., 2016; Yeoman and McMahon-Beatle, 2016). Portugal has 29 DOC wine regions and Portuguese culinary traditions are both rich and varied and it was elevated to national heritage status in 2000 (Moreira, 2018). Additionally, Moreira (2018) refers that Portuguese wines are internationally recognized as being of high quality and variety. In fact, regional products have functioned as a driver of regional attractiveness and competitiveness (Brás et al., 2010; Silva, Fernão-Pires and Bianchi-de-Aguiar, 2018).

The search for leisure in outdoor spaces or in nightlife indoor areas is another of the motivations highlighted in the literature (Hollands and Challerton, 2003; Tutenges, 2012). Leisure activities promoted by regional government and local agencies, the nightlife areas in the historic centre of the city of Porto and in its metropolitan area, and the organization of sports events have been areas in which Portugal's tourism has been privileged (Silva and Silva, 2003). Over the years a number of facilities have been built to accommodate big events in Porto: EXPONOR - Feira International do Porto, Matosinhos (1987), in a highly versatile precinct which accommodates various types of events; the Multiusos de Guimarães, Multipurpose Hall (2001); Casa da Música, Porto (2005). In 2016, Portugal was in 10th place worldwide, having hosted 287 various major types of events, positioning Porto in the 31 st place, having held 70 international associative events (International Congress and Convention Association, 2016).

Portugal has an enormous variety of landscapes and high diversity of natural habitats, with conditions that allow the realization of programs in an outdoor environment, such as the practice of nature and mountain tourism or the observation of birds in habitats as distinct as escarpments, lagoons, plains or estuaries. The mild climate throughout the year turns possible to carry out a wide range of outdoor activities every month of the year. Portugal has $21 \%$ of the national territory considered Network of Protected Natural Areas (Carneiro, 2007; Cravidão and Cunha, 2017; Gavinho and Silva, 2017).

Once the importance and correlation between religious and cultural tourism are identified, with the other diversities of complementary motivations, it is, therefore, essential to create and strengthen synergies between localities and municipalities, in order to complement and optimize the offer. According to Santos (2006), reporting to several empirical studies, they clearly indicate that the existence of synergies between cultural and religious tourism and, logically, also in complementarily with other types of tourism, results in an increase in the number of visitors, paraphrasing the author, "the cultural goods in the vicinity of centers of religious attraction have a much higher number of visitors than goods of artistic value which are situated in regions without important religious centers, regardless of the artistic value of some goods." According to Cunha (2013) citing Pinto (2011), he argues that religion has always been the spiritual motor of all civilizations and no historical civilization has developed 
outside a religion, a view shared by Teixeira and Romão (2013), who see religion as an identity phenomenon of each culture. Ambrósio (2006) states that according to the UNWTO (2017), religious motivation is among the main motivations of tourist travel, surpassing the motivations of holiday tourism and business in terms of growth. In the Portuguese case, $91 \%$ of tourists who visited Portugal in 2012 expressed their desire to return to Portugal in the next three years, considering the religious destination Fátima, one of the five preferred destinations of choice. Thus, religious tourism assumes the role of cultural agents, important in all their manifestations, the protection of ancient values, intervention in society and prevention, in the definition of the future policies of individuals and societies (Dias, 2010).

Currently, Business Tourism represents a significant weight in local and regional economies and corresponds to a tourism segment with great potential for development (Carvalho et al., 2018; Nicula and Elena, 2014). In Portugal, for some years now, some strategies have been pointed out for the development of Business Tourism, more specifically through the National Strategic Plan of Tourism of Portugal 2007 and more recently the Tourism Strategy 2027 (Turismo de Portugal, 2018). In this context, the organizational structures called Convention \& Visitors Bureau (CVB) play a key role in structuring the product and communication/promotion of the offer, as well as in projecting territories as Business Tourism destinations, and in prospecting and attracting business and public events. Considered one of the main segments of tourism, it is estimated that it will grow annually by $3.1 \%$ until 2030 (UNWTO, 2011), and clearly has a set of differentiating characteristics, which include aid to combat the phenomenon of seasonality; increased profitability that it represents for cultural spaces (auditoriums, movie theatres, cultural centers, and other event spaces); and the consequent increase in hotel occupation rates.

In 2015, Business Tourism represented $14 \%$ of the global international arrivals, while Holiday, Recreation and Leisure trips account for more than half of the global number of international arrivals (53\%), compared to the other motivations, such as visits to family and friends, religious reasons and pilgrimages, health and well-being treatments, among others, represent only $27 \%$ of the global value (UNWTO, 2017). In this sequence, the city of Porto in the Business Tourism segment, and based on the study of secondary data published by the International Congress and Convention Association (ICCA) concerning the evolution of the market for associative meetings in the global market, as well as the identification of some reference equipment (venues), which consists of the Customs Congress Centre of Porto, which over the last few years has been recognized at national and international level with the award of several prizes (Europe's Best Meetings \& Conference Centre in 2014 and 2015, by Business Destinations; Best Congress Space in 2013 and 2014, by the Publituris Portugal Travel Awards; Best Congress Centre in 2006, 2011, 2012, 2013 and 2015, by the Events/Events Gala; Best National Supplier 2014, by the International Association of Professional Congress Organizers - IAPCO). Pinho and Marques (2019) state that with this investment, the city of Porto has currently a large capacity structure for conducting business events, thus contributing even more to the increased competitiveness of both the city and the region where it operates.

\section{Methodology}

\subsection{Research Dimensions}

The pull factors identified in the literature can be summarized into ten variables: (i) cultural motive (CM); (ii) entertainment and nightlife (EN); (iii) shopping (SHOP); (iv) education (EDUC); (v) festivals and other cultural events (FOCE); (vi) gastronomy (GAST); (vii) natural values (NV); (viii) sport and sport events (SSE); (ix) business motive (BM); and (x) religious motive (RM). These variables correspond to the pull motives that are systematically and transversally mentioned in the literature. According to Bozic et al. (2017), four 
dimensions of pull factors can be considered and result from the combination of pull factors variables, such as: (i) self-improvement, which includes cultural motive and education; (ii) leisure activities, which brings together the entertainment and nightlife and shopping dimensions; (iii) hedonic consumption, which includes festivals and other cultural events and gastronomy; and (iv) active vacation, which aggregates the nature and sport and sport events dimensions. The business motives and religious motives were kept isolated, and these dimensions correspond to the same variables. These pull variables can also be combined in another way, namely through the aggregation between cultural motives and gastronomy. According to Graham et al. (2016) and Matta (2015), the gastronomy is, in general, the set of cultural practices related to food represent an important element of social differentiation. In this sense, the hedonic consumption can also include gastronomy and cultural motive. Consequently, the cultural motive variable is shared between the self-improvement and hedonic consumption dimensions. Table 1 summarizes the correspondence between dimensions and variables, and associates them with the main authors that support these dimensions.

Table 1: Hierarchical organization of dimensions and variables.

\begin{tabular}{|l|l|l|}
\hline Dimensions & Variables & Authors \\
\hline Self-improvement & $\begin{array}{l}\text { Cultural motive } \\
\text { Education }\end{array}$ & $\begin{array}{l}\text { Correia (2018); Remoaldo } \\
\text { et al. (2014); UNESCO } \\
\text { (2014) }\end{array}$ \\
\hline Leisure activities & $\begin{array}{l}\text { Entertainment and } \\
\text { nightlife } \\
\text { Shopping }\end{array}$ & $\begin{array}{l}\text { Hollands and Challerton } \\
\text { (2003); Silva and Silva } \\
\text { (2003); Tutenges (2012) }\end{array}$ \\
\hline $\begin{array}{l}\text { Hedonic } \\
\text { consumption }\end{array}$ & $\begin{array}{l}\text { Festivals and other cultural } \\
\text { events } \\
\text { Gastronomy }\end{array}$ & $\begin{array}{l}\text { Moreira (2018); Sormaz et } \\
\text { al. (2016); Yeoman and } \\
\text { McMahon-Beatle (2016) }\end{array}$ \\
\hline Active vacation & $\begin{array}{l}\text { Nature } \\
\text { Sport and sport events }\end{array}$ & $\begin{array}{l}\text { Carneiro (2007); Cravidão } \\
\text { and Cunha (2017); Gavinho } \\
\text { and Silva (2017) }\end{array}$ \\
\hline Business motives & Business motives & $\begin{array}{l}\text { Carvalho et al. (2018); } \\
\text { Nicula and Elena (2014); } \\
\text { UNWTO (2011); UNWTO } \\
\text { (2017) }\end{array}$ \\
\hline Religious motives & Religious motives & $\begin{array}{l}\text { Ambrósio (2006); Dias } \\
\text { (2010); Pinto (2011); } \\
\text { Santos (2006) }\end{array}$ \\
\hline
\end{tabular}

\subsection{Procedure}

Measuring the motivations of tourists is a challenging task. The data needed to carry out a quantitative study are not always available or structured in the ideal form for consolidation. Furthermore, there are also subjective aspects to be considered, whose measurements are necessarily even more complex. In this sense, it is necessary to employ an evaluation method that allows assessing the relative importance of pull factors for the city of Porto. Therefore, the analytical hierarchy process (AHP) method was used. This method has been adopted mainly in the area of engineering, education and economics, but has also in recent years been progressively adopted for the tourism sector (Almeida and Amoedo, 2018; Bahadori et al., 2017; Barghash et al., 2017; Hoang et al. 2018). 
The AHP method was developed in the 1970s by Thomas L. Saaty. The AHP multicriteria approach is applied in decision making in complex environments where several variables or criteria are considered for the prioritization and selection of alternatives in various complex scenarios. These complex scenarios typically include people working together to make a decision, the need to perceive human perceptions, their judgments and explore long-term consequences of their decisions (Saaty, 2008).

The central idea of the AHP method is to reduce the study of systems to a peer-to-peer comparison sequence. The usefulness of the method is realized in the decision-making process, minimizing its failures. Bernasconi et al. (2010) state that AHP theory reflects the natural method of functioning of the human mind, in which an individual faced with a large number of elements, the human mind aggregates them into groups according to common characteristics. The brain repeats this process and again groups the elements according to the various levels. The systematic repetition of this process reaches its maximum level when it represents the objective of our decision-making process.

According to Saaty (2013), one of the great advantages of AHP is the inclusion of qualitative and quantitative aspects of a decision-making problem. The values of the judgments of parity comparisons are based on physical data, but also on the experience and intuition of the individual. Accordingly, the application of AHP includes and measures all important qualitative and quantitatively measurable factors, whether tangible or intangible, to come closer to a realistic model.

AHP makes peer comparisons at each level of the hierarchy based on the AHP priority scale, individuals assign relative weights, called priorities, to differentiate the importance of the criteria. However, to apply correctly the priority scale it is necessary to understand what the judgments are in the method created by Saaty. A judgment or comparison is the numerical representation of a relationship between two elements, and this judgment can be represented in a square matrix. For this purpose, the Saaty scale is adopted. The Saaty scale ranges from 1 to 9 , in which 1 means the indifference of importance of one criterion in relation to the other, while 9 means the existence of extreme importance of one criterion over another. The judgment reflects the answers to two questions: (i) which of the two elements is most important with respect to a higher level criterion, and (ii) with what intensity, using the Saaty scale.

The number of judgments required for the construction of a generic judgment matrix $\mathrm{A}$ is (n-1)/2, where $n$ is the number of elements belonging to this matrix. The structure of a matrix applying the AHP method is exemplified in Figure 1. All diagonal elements are always equal to 1 , because an element is equally important to itself. To fill the other elements of the matrix outside the diagonal, the judgments are made and the intensity of importance is determined according to the Saaty scale. The lower left part of the matrix is filled with the reciprocal values of those of the upper right part of the matrix.
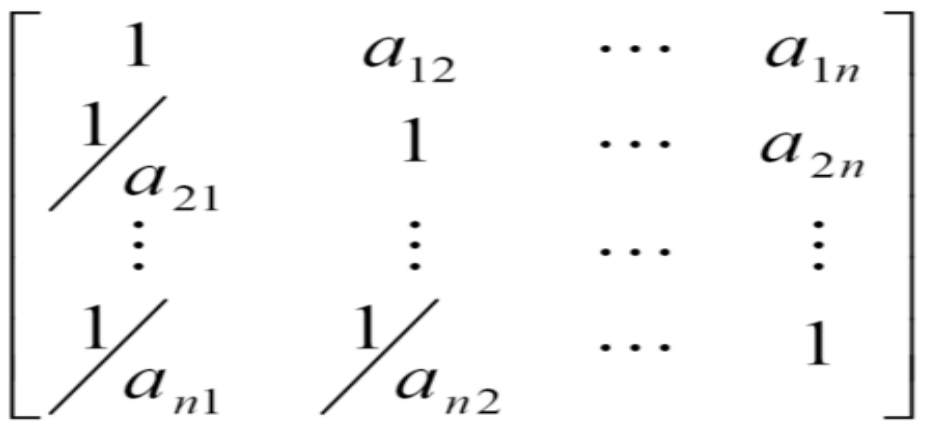

Figure 1: Structure of the matrix in the AHP method. Source: (Saaty, 2013). 
Chan et al. (2004) summarize the necessary steps in the application of the AHP method:

1. Define the problem and break it down according to its hierarchies, namely by identifying objectives, criteria and alternatives. In our study the alternatives were not considered, because all interviewed tourists were already visiting the city of Porto;

2. Construct an equal comparison matrix between the elements of the lower level and those of the level immediately above. The comparison of the elements of this matrix must be done using the Saaty scale;

3. Calculate the consistency index (CI) according to the expression below. $\lambda$ max is the largest eigenvalue of the judgment matrix. Saaty (2013) states that CI must be less than 0.1 to proceed with the AHP calculations. If the consistency index is higher than this value, then it is recommended that the judgments be rewritten by rewriting the survey or re-categorizing elements, until the consistency increases; IC $=(\lambda$ máx $-n) /(n-$ 1)

4. Calculate local and global priorities, compare alternatives and select the best option. This process involves the following operations: (i) normalization of judgment matrices; (ii) calculation of local average priorities; and (iii) calculation of global priorities.

The AHP method is typically applied in small samples through the realization of semistructured interviews of more than 30 minutes to 1 hour. According to Cheng et al. (2002), the application of the AHP method is possible in larger samples, but in very specific contexts in which there are several respondents. In this sense, this study involved 26 students from the tourism course to conduct each survey.

Prior to the survey, the students were trained in the AHP method by the course coordinator. Additionally, and in order to reduce the time of each survey, only the pairs of comparison of the 3 most important criteria indicated by the respondent were considered. This situation turned possible to develop a survey with a response time of less than 10 minutes without compromising the validity of the obtained results, since the number of surveys carried out was more than twice those indicated in the studies carried out by Hsu et al. (2009) that employed a sample of 32 respondents in the use of the AHP method for the construction of a decision support system in the choice of a tourist destination and Bozic et al. (2017) that also adopted the AHP method for the analysis of tourist motivations in visiting the Ljubljana city.

\subsection{Research Design and Process}

The methodology is organized into three phases as depicted in Figure 2. In the preliminary stage, an analysis of the literature on the push-pull theory and urban travel motivations was performed. This analysis allowed us to define the variables and dimensions of the pull factors that are fundamental in the construction of the survey. The survey was then carried out by tourism students from a Portuguese higher education institution during November 2018 in the historic centre of the city of Porto and V.N.Gaia, near the Douro river.

The surveys were conducted in English and respondents were asked to express their preferences regarding the reasons for their visit to the city of Porto. The mapping of these responses was subsequently carried out by the students using the Saaty's scale. Finally, in the evaluative stage the survey, data were analyzed using MS Excel and SPSS software. The results obtained were subsequently compared with the existing literature in the field and the main conclusions were drawn. 


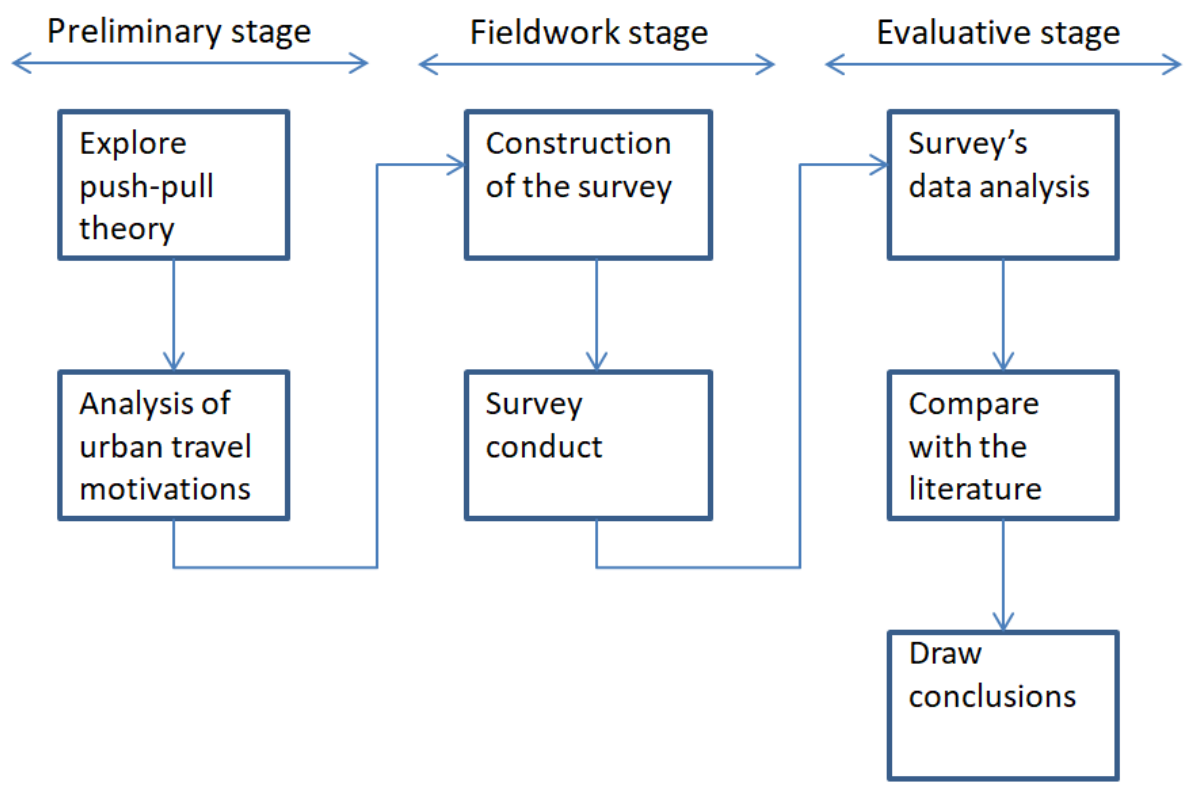

Figure 2: Phases of the adopted methodology.

The study employed surveys to collect the preferences of the motives of tourists visiting the city of Porto. The adoption of surveys allowed us to collect quantitative data that can then be compared and draw conclusions regarding the importance of each pull factor. According to Creswell (2018), surveys can be used for three purposes: (i) data exploration, in which a greater familiarity with the problem is sought in order to make it more explicit; (ii) description, in which the primary objective is to describe the characteristics of a phenomenon or the establishment of relationships of variables; and (iii) explanation, in which the main objective is to identify the factors that determine or contribute to the occurrence of certain phenomena. In the study developed, an exploratory survey was developed, which seeks to comparatively assess the relative importance of the motivations of tourists who visit the city of Porto.

Several benefits are typically associated with the surveys, namely their efficiency in collecting information from a large number of respondents and the possibility of using statistical techniques to determine the validity and reliability of the identified results (Cresswell, 2018; Queirós et al., 2017). However, it is also possible to find in the literature some of the disadvantages of the surveys that include (Cresswell, 2018; Fowler, 2013): (i) high dependence on respondents' motivation to participate; (ii) low validity of the reliability of the answers when the number of questions is closed and too high; and (iii) errors and deviations may arise due to the lack of complete answers. Therefore, this study adopted the following mitigation practices: (i) all interviewees indicated their consent to participate in the survey; (ii) the survey is small in size and was designed so that the total time of each response was less than 10 seconds; (iii) the AHP method was used to assess the relative importance of each pull factor; (iv) a final question was defined to post comments on the answers given by the respondents, which also allowed to collect qualitative data; and (v) the surveys in which it was not possible to identify the motivations of visits were not considered for statistical purposes.

\subsection{Study Sample}

A total of 75 tourists who visited the city of Porto during November 2018 participated in this study. However, 4 incomplete surveys were dropped and, therefore, the final sample includes 71 surveys. In addition, due to the confidentiality of the information, only 59 respondents disclosed their academic background and 29 of them provided data on their monthly income. 
Most respondents are male and are between 17 and 27 years old. Most of the respondents are from the UK followed by France, Spain, and Brazil. Additionally, more than $60 \%$ of respondents have a university education and more than $80 \%$ of respondents have monthly incomes between $500 €$ and $2999 €$. Only 2 respondents $(6.90 \%)$ indicated to have a monthly income superior to $4000 €$. Detailed information on the socio-demographic characteristics of the respondents is given in Table 2.

Table 2: Socio-demographic characteristics.

\begin{tabular}{|c|c|c|}
\hline Variable & $\begin{array}{l}\text { Absolute } \\
\text { frequency }\end{array}$ & $\begin{array}{l}\text { Relative } \\
\text { frequency }\end{array}$ \\
\hline \multicolumn{3}{|l|}{ Gender $(n=71)$} \\
\hline Male & 40 & $56.34 \%$ \\
\hline Female & 31 & $43.66 \%$ \\
\hline \multicolumn{3}{|l|}{ Age $(n=71)$} \\
\hline 17-27 years old & 16 & $22.54 \%$ \\
\hline $28-37$ years old & 13 & $18.31 \%$ \\
\hline $38-47$ years old & 11 & $15.49 \%$ \\
\hline $48-57$ years old & 13 & $18.31 \%$ \\
\hline 58-67 years old & 11 & $15.49 \%$ \\
\hline 68-77 years old & 7 & $9.86 \%$ \\
\hline \multicolumn{3}{|l|}{ Country of origin $(n=71)$} \\
\hline UK & 14 & $19.72 \%$ \\
\hline France & 10 & $14.09 \%$ \\
\hline Spain & 6 & $8.45 \%$ \\
\hline Brazil & 6 & $8.45 \%$ \\
\hline Portugal & 5 & $7.04 \%$ \\
\hline Germany & 4 & $5.63 \%$ \\
\hline Switzerland & 4 & $5.63 \%$ \\
\hline Others & 22 & $30.99 \%$ \\
\hline \multicolumn{3}{|l|}{ Education $(n=59)$} \\
\hline Secondary school & 12 & $20.34 \%$ \\
\hline Higher school & 10 & $16.95 \%$ \\
\hline Faculty & 16 & $27.12 \%$ \\
\hline Master/PhD degree & 21 & $35.59 \%$ \\
\hline \multicolumn{3}{|l|}{ Monthly Income $(n=29)$} \\
\hline Between 500 and $999 €$ & 8 & $27.59 \%$ \\
\hline Between 1000 and $1999 €$ & 8 & $27.59 \%$ \\
\hline Between 2000 and $2999 €$ & 8 & $27.59 \%$ \\
\hline Between 3000 and $3999 €$ & 3 & $10.33 \%$ \\
\hline Equal or more than $4000 €$ & 2 & $6.90 \%$ \\
\hline
\end{tabular}

\section{Results}

\subsection{Ranking of the Pull Motives}

Data from the survey were mapped into MS Excel and analyzed using the AHP add-on provided by XLSTAT. The CI is equal to $0.01 \quad(\mathrm{CI}<0.1)$, indicating that the comparison between the criteria was performed with homogeneity. Figure 3 shows the final ranking of tourist motives for visiting Porto. These motives are decreasingly organized, starting from the most dominant to the least dominant motive. The motivations to visit the city of Porto are not 
uniformly distributed, being that two reasons stand out (e.g., cultural motive and gastronomy). These two reasons together have a weight of more than $50 \%$ considering all the pull variables.

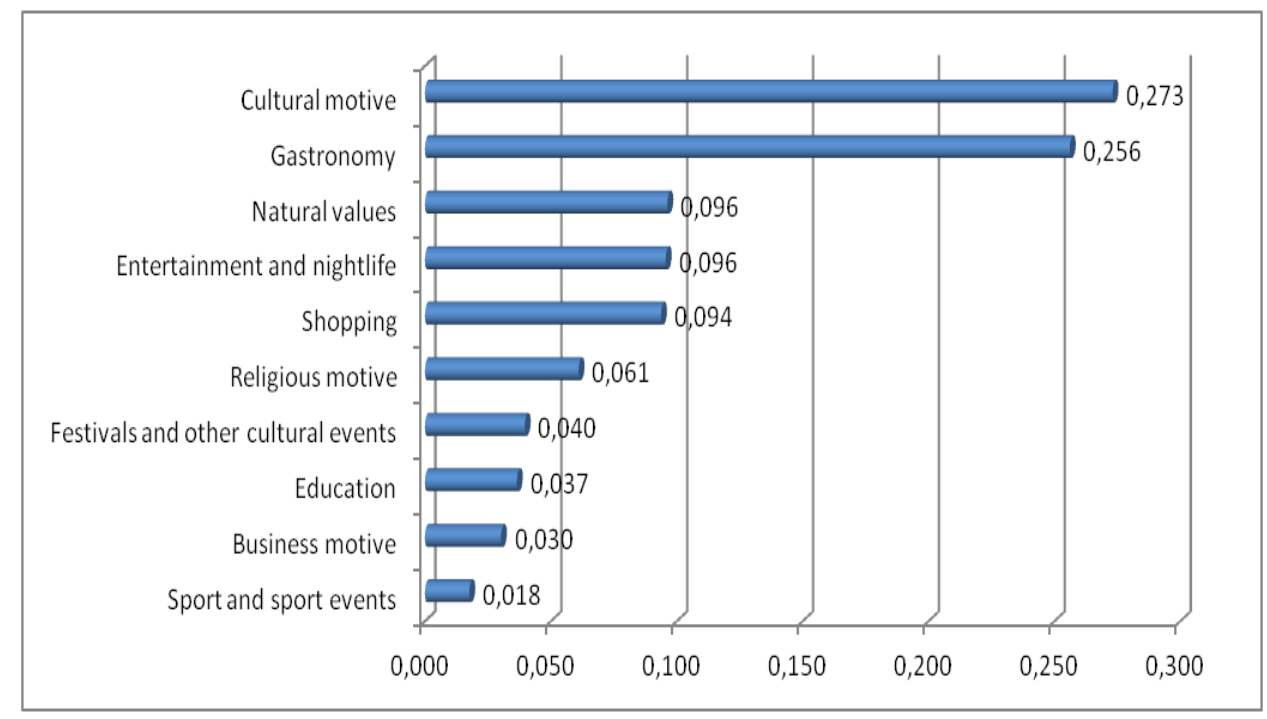

Figure 3: Ranking of motives to visit Porto.

In the first place, cultural motives are the main factor for visiting the city of Porto. In fact, culture is an essential part of Porto. The Historic Centre of Porto is the oldest area of Porto classified as a World Heritage Site by UNESCO since 1996. Besides the historic centre, the city is full of diverse cultural options with more than 40 museums, 20 cinemas and 12 theatres, and art galleries. There are several buildings such as the Sé Cathedral (Romanesque style of the 12th century), Fernandina Wall (Gothic style of the 14th century), Church and Tower of Clérigos (Baroque, 18th century), or the Stock Exchange Palace (neoclassical and romanticism of the 19th century). Porto's cultural offer is complemented by the famous local gastronomy that mixes Mediterranean and Atlantic traditions. When talking about Porto, it is imperative to mention some traditional dishes, among which, due to its history, the Porto-style Tripas stand out, a dish that gives its name to the city's inhabitants (Tripeiros). From Porto, there are also the cod and meat dishes and a secular sweets shop with great flavour and richness. Furthermore, the Douro wine valley is a famous center for the production of Porto's wine, and is also classified as a UNESCO World Heritage Site. In fact, several respondents expressed that wine tourism is an important component of their decision to visit Porto. According to Thanh and Kirova (2018), wine tourism is a segment of the tourist activity that is based on the journey motivated by the appreciation of the taste and aroma of the wines and the traditions and culture of the localities that produce this drink. In the city of Porto, wine tourism stands out as having a relevant role in the motivation of tourists, which in our study was framed within the gastronomic motivations. In this sense, the second place of gastronomy in the ranking of reasons is not a surprise.

The second group of pull motives includes natural values, entertainment and nightlife, and shopping. Although these elements have some relevance, their impact on tourists' decisions is much smaller than the two previous criteria. Porto essentially serves as a point of arrival for tourists that wish to visit the northern region of Portugal, which is characterized by beautiful landscapes, mountains, plains, valleys, and very rich fauna and flora. This region offers to all visitors the healthy experience of getting involved with nature and enjoying idyllic environments marked by the diversity of natural resources and protected natural spaces such as the National Park of Peneda Gerês. Also, a tourist reference in the north of Portugal is the Douro Valley, classified by UNESCO as a World Heritage Site. The International Douro 
Natural Park is an area rich in ethnological traditions and its landscape is marked by vineyards and olive groves. Although Porto offers several spaces for entertainment and nightlife, and shopping, it is found that this offer is inferior to Lisbon and the Algarve regions in the south of the country.

Less relevant elements in the motivation of tourists visiting Porto are the religious motive, festivals and other cultural events, education, business motive, sport and sport events. Two of these factors deserve special attention due to their characteristics and articulation with other external factors. The religious motive is somehow related to cultural motives since a significant part of the cultural offer includes churches, monasteries, and Catholic monuments. Despite this, the importance of religious motivation in Porto is lower than in other cities in Portugal, such as Fatima, which is a shrine of the Catholic Church, and it is by excellence a place of Catholic devotion. In education, the role of the University of Porto in organizing international congresses and the role of the university in attracting mobility students stand out. In 2018, the University of Porto set a new national record by receiving almost 2500 foreign students through mobility programmes like Erasmus+ and Erasmus Mundus (Silva, 2018).

Finally, it is also important to explore other pull factors mentioned by the respondents which were recorded in the comments field of the survey. Three factors stand out: (i) lower travel and local services prices; (ii) sympathy of the Portuguese people; and (iii) safety. The lower prices are due to the location close to Porto airport and the relatively low cost of living in Portugal when compared to other European destinations (Costa and Almeida, 2018; Leffel, 2018). The sympathy of the Portuguese is highlighted by differences in agencies, and Portugal was considered in 2018 the most welcoming country for expats (Southan, 2018). The security of goods and people is also another factor that attracts tourists to Portugal. Real (2018) states that Portugal was considered the 4th most peaceful country in the world and the 3rd safest country in Europe considering the 2018 Global Peace Index (GPI).

\subsection{Categorization of Pull Motives}

A hierarchical analysis of the travel pull factors allows us to identify several combinations of pull motives. These categories allow us to explore eventual association among pull factors and identify emergent patterns. Two pull factors stand out (e.g., cultural motive and gastronomy) when exploring the reasons to visit the city of Porto. The approach proposed by Graham et al. (2016) and Matta (2015) advocate the aggregation of these two variables in the hedonic consumption dimension. Figure 4 allows you to analyze the categorization of pull motives that are ordered decreasingly by their importance.

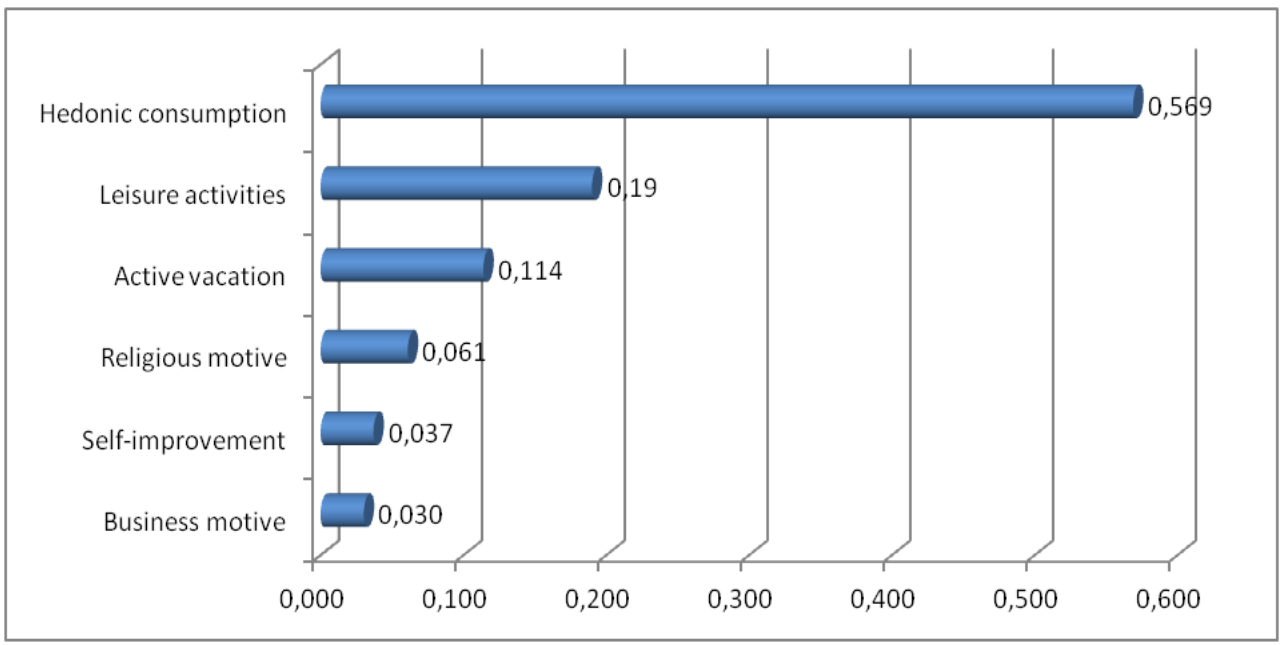

Figure 4: Ranking of categories of pull factors. 
The obtained results emphasize the importance of hedonic consumption dimension, which includes three variables (cultural motive, gastronomy, and festival and other cultural events). Secondly, at a very significant distance, leisure activities and active vacation appear. In an increasingly globalized world, gastronomy is an important element in attracting tourists. Metcalfe and McWhirter (2017) highlight the role of wine and food lovers in attracting tourists to Portugal. In this sense, "food travellers" assume themselves as a fundamental part of the cultural manifestation and as the intangible heritage of a region (Dixit, 2019). Additionally, Martins (2016) and Privitera et al. (2018) state that gastronomy and tourism also provide a platform for local economic development that, through the offer of unique gastronomic experiences, help to create a brand and sell destinations, as well as support the development of local culture. The city of Porto was considered the second best destination for culture in the world in 2019 (Irving, 2019).

On the opposite side, the three least motivation factors include: (i) business motive; (ii) self-improvement; and (iii) religious motive. The attraction of tourists to the city of Porto through business motivation and self-improvement are somehow associated. The number of events held in the city of Porto compared to other European cities is still low. Nevertheless, in recent years, efforts have been made by the University of Porto and the Porto Tourism Association to organise international conferences and congresses that enhance the visibility of the city of Porto. Bexiga (2017) highlights the rise of Porto in the business tourism segment, having been in 2017 the European destination that grew the most in the top 50. Regarding the religious motive, the city of Porto has high competition from other cities in Portugal such as Fatima, which is one of the main centres of Catholic devotion in Europe.

\section{Conclusion, Implications and Limitations}

In the growing phenomenon of global tourism, cities have become attractive for tourist activity. On the one hand, cities must be able to meet the expectations and needs of a growing number of tourists, attracted by the richness and variety of architecture, culture, gastronomy, among others. From another perspective, they must ensure the sustainability of tourism development by ensuring that it is managed in a way that benefits the resident population and does not deteriorate the characteristic urban environment.

Porto is one of the fastest growing European tourist destinations, with exponential growth in the demand for city-break tourists. The city of Porto has received several international awards, namely by the European Consumers Choice in 2012, 2014 and 2017, and also the second best destination for culture in the world in 2019. Porto has a cultural, monumental, historical and gastronomic offer with enormous potential for tourist attraction.

This study employed the AHP method to explore the pull factors of urban tourists' motivations to visit the city of Porto. The AHP method proved to be effective in establishing a pull factor ranking that allows a comparative assessment of the importance of each pull factor for evaluating tourist motivations that visit the city of Porto. The results of this study turned possible to identify the hedonic consumption dimension as being the main factor in the motivation of tourists to visit Porto. In this hedonic consumption dimension are included the cultural motive and gastronomy variables, which together represent more than $50 \%$ of the tourist motivations.

This study is particularly relevant for tourism professionals and can help them develop strategies for promotion, communication, and segmentation. The importance of hedonic consumption dimension reflects the importance of tourism operators' commitment to offering authentic experiences based simultaneously on the cultural and gastronomy variables. Therefore, tourism operators should develop offers of authentic experiences that integrate holistic consumption dimension and that contribute to combating tourist seasonality and 
stimulate the sustainability of the local environment, cultural heritage and strengthening local identities and the sense of community.

One of the main limitations of this study is the consideration only of pull factors. In this sense, it would be relevant to develop a study in which the push factors were also explored and a relationship could be established between both factors in the analysis of the tourist attractiveness of the city of Porto. Another limitation of this study is that pull factors are not organized hierarchy. In this sense, in future work, the AHP method should consider multiples levels of criteria. Furthermore, the qualitative information collected from the respondents was not systematically used in the construction of pull factors. A future study should seek to introduce this data in the survey.

\section{References}

Almeida, F. and Amoedo, N. (2018). Decision Support System For Internship Management in Higher Education. International Journal of Information Systems and Social Change, 9(1), 40-57.

Ambrósio, V. (2006). Turismo Religioso: Desenvolvimento das Cidades - Santuário. (Tese de Doutoramento). Universidade Nova de Lisboa, Portugal.

Bahadori, M., Malmir, R., Alimohammadzadeh, K., Yaghoubi, M. and Hosseini, S. (2017). Identifying and Prioritizing Barriers to Health Tourism Using the Analytical Hierarchy Process. International Journal of Travel Medicine and Global Health, 5(1), 33-35.

Baloglu, S. and Uysal, M. (1996). Market segments of push and pull motivations: a canonical correlation approach. International Journal of contemporary Hospitality Management, 3(8): 32-38.

Barghash, M., Al-Qatawneh, L., Ramadan, S. and Dababneh, A. (2017). Analytical Hierarchy Process Applied to Supermarket Layout Selection. Journal of Applied Research on Industrial Engineering, 4(4), 215-226.

Bernasconi, M., Choirat, C. and Seri, R. (2010). The Analytic Hierarchy Process and the Theory of Measurement. Management Science, 56, 699-711.

Bexiga, S. (2017). Turismo de negócios: Porto ascende aos 20 primeiros destinos da Europa. Retrieved May 19, 2019, from https://jornaleconomico.sapo.pt/noticias/turismo-denegocios-porto-ascende-aos-20-primeiros-destinos-da-europa-155827.

Bozic, S., Kennell, J., Vujicic, M. and Jovanovic, T. (2017). Urban tourist motivations: why visit Ljubljana? International Journal of Tourism Cities, 3(4), 382-398.

Brás J. M., Costa C. and Buhalis D., (2010), Networks analysis and wine routes: The case of the Bairrada wine route, Portugal, The Services Industries Journal, 30 (10), 1-21.

Carneiro M. J. (2007). Modelling the choice of tourism destinations: a positioning analysis (PhD thesis). University of Aveiro, $492 \mathrm{p}$. Available at: https://ria.ua.pt/bitstream/10773/1841/1/2008000379.pdf.

Carvalho, P., Márquez, M. and Diaz-Méndez, M. (2018). Policies to increase business tourism income: A dynamic panel data model. Journal of Convention \& Event Tourism, 19(1), 63-82.

Chan, A., Kwok, W. and Duffy, V. (2004). Using AHP for determining priority in a safety management system. Industrial Management \& Data Systems, 104(5), 430-445.

Cheng, E., Li, H. and Ho, D. (2002). Analytic hierarchy process (AHP): A defective tool when used improperly. Measuring Business Excellence, 6(4), 33-37.

Comissão de Coordenação e Desenvolvimento Regional do Norte (CCDRN) (2011). Programa Regional de Reformas Norte 2020. Public Consultation Document. In portuguese, Porto: CCDRN. Available at: http://www.ccdr-n.pt/node/415.

Correia, L. (2018). Landscape and Cultural Heritage from Portugal: Images of National Resurgence. Estudos do Século XX, 18, 189-219. 
Costa, V. and Almeida, C. (2018). Low cost carriers and tourism destinations development: case study of Oporto, Portugal. Tourism \& Management Studies, 14(2), 7-15.

Cravidão, F. and Cunha, L. (2012). Regional and Local Responses in Portugal. Coimbra: Imprensa da Universidade de Coimbra.

Creswell, J. (2018). Research Design: Qualitative, Quantitative, and Mixed Methods Approaches. Thousand Oaks, California: SAGE Publications.

Cunha, L. (2012). Turismo em Portugal: sucessos e insucessos. Lisboa: Edições Universitárias Lusófonas.

Cunha, L. (2013). Economia e Política do Turismo. Lisboa: Lidel.

Dann, G. (1977). Anomie, ego-enhancement and tourism. Annals of Tourism Research, 4, 184-194.

Dias, I. N. (2010). Turismo cultural e religioso no Distrito de Coimbra: mosteiros e conventos: viagem entre o sagrado e profano (Dissertação de Mestrado, da Faculdade de Letras da Universidade de Coimbra, Portugal. Available at: https://eg.sib.uc.pt/bitstream/10316/15296/1/Disserta\%c3\%a7\%c3\%a3o\%20mestrado_I sabel\%20Dias.pdf.

Dixit, S. (2019). The Routledge Handbook of Gastronomic Tourism. Boca Raton, Florida: Routledge International Handbooks.

Dunn, B. (2009). Global Political Economy: A Marxist Critique. London: Pluto Press.

Fowler, F. (2013). Survey Research Methods. Thousand Oaks, California: SAGE Publications.Gavinho, E. C. and Silva, M. (2017). Espaços naturais: o desafio de planear um destino turístico. In F. Silva and J. Umbelino (Eds.), Planeamento $e$ Desenvolvimento Turístico (pp. 451-464). Lisboa: Lidel.

Graham, R., Hodgetts, D. and Stolte, O. (2016). Dual-heritage households: Food, culture, and re-membering in Hamilton, New Zealand. International Review of Social Research, 6(1), 4-14.

Hoang, H., Truong, Q., Nguyen, A. and Hens, L. (2018). Multicriteria Evaluation of Tourism Potential in the Central Highlands of Vietnam: Combining Geographic Information System (GIS), Analytic Hierarchy Process (AHP) and Principal Component Analysis (PCA). Sustainability, 10(9), 1-20.

Hollands, R. and Chatterton, P. (2003). Producing Nightlife in the New Urban Entertainment Economy: Corporatization, Branding and Market Segmentation. International Journal of Urban and Regional Research, 27(2), 361-385.

International Congress and Convention Association (ICCA). (2016). The International Association Meetings Market 2015. Amsterdam: ICCA.

Irving, I. (2019). Culture Trip Wishlist: The 12 Cities To Visit in 2019, Ranked. Retrieved March 17, 2019, from https://theculturetrip.com/europe/articles/culture-trip-wishlistdestinations-2019/.

Jeong, C. (2014). Marine Tourist Motivations Comparing Push and Pull Factors. Journal of Quality Assurance in Hospitality \& Tourism, 15(3), 294-309.

Kim, S., Lee, C. and Klenosky, D. (2003). The influence of push and pull factors at Korean national parks. Tourism Management, 24(2): 169-180.

Leffel, T. (2018). What it costs to live in Portugal. Retrieved March 19, 2019, from https://www.cheapestdestinationsblog.com/2018/07/13/what-it-costs-to-live-inportugal/.

Lubbe, B. A. (2003). Tourism management in Southern Africa. Cape Town: Pearson Education South Africa.

Mahika, E. (2011). Current trends in tourist motivation. Cactus Tourism Journal, 2(2), 15-24.

Martins, M. (2016). Gastronomic tourism and the creative economy. Journal of Tourism, Heritage \& Services Marketing, 2(2), 33-37. 
Matta, R. (2015). Anthropology of food. In Ronda L. Brulotte and Michael A. Di Giovine (Eds.), Edible Identities: Food as Cultural Heritage. Retrieved March 17, 2019, from http://journals.openedition.org/aof/78244.

Metcalfe, C. and McWhirter, K. (2007). The Wine and Food Lover's Guide to Portugal. San Francisco, California: Wine Appreciation Guild.

Ministério da Economia e da Inovação (MEI) (2007), Plano Estratégico Nacional do Turismo. Para o Desenvolvimento do Turismo em Portugal 2006-2015, Ministério da Economia e da Inovação e Turismo de Portugal, Lisboa. Available at: https://travelbi.turismodeportugal.pt/pt-pt/Documents/Estratégia/PENT_2007.pdf.

Moreira, C. (2018). Portugal as a tourism destination - paths and trends. Méditerranée. Available at: https://journals.openedition.org/mediterranee/10402\#entries.

Nicula, V. and Elena, P. (2014). Business Tourism Market Developments. Procedia Economis and Finance, 16, 703-712.

Nikjoo, A. and Ketabi, M. (2015). The role of push and pull factors in the way tourists choose their destination. Anatolia - An International Journal of Tourism and Hospitality Research, 26(4), 588-597.

Phau, I., Lee, S. and Quintal, V. (2013). An investigation of push and pull motivations of visitors to private parks: The case of Araluen Botanic Park. Journal of Vacation Marketing, 19(3), 269-284.

Pinho, M. and Marques, J. (2019). Perspectives for Development of Business Tourism in Porto. In Proceedings of the 2nd International Conference on Tourism Research, Porto, Portugal.

Pinto, S. (2011). Turismo Religioso - potencial de desenvolvimento da Vila de Arcozelo, Vila Nova de Gaia (Dissertação de Mestrado, da Universidade Lusófona de Humanidades e Tecnologias, Lisboa, Portugal). Available at: http://recil.grupolusofona.pt/bitstream/handle/10437/2877/Dissertação\%20Cátia\%20Pin to.pdf?sequence $=1$.

Prayag, G. and Ryan, C. (2011). The relationship between the 'push' and 'pull' factors of a tourist destination: the role of nationality - An analytical qualitative research approach. Current Issues in Tourism, 14(2): 121-143.

Privitera, D., Nedelcu, A. and Nicula, V. (2018). Gastronomic and food tourism as an economic local resource: case studies from Romania and Italy. GeoJournal of Tourism and Geosites, 21(1), 143-157.

Queirós, A., Faria, D. and Almeida, F. (2017). Strengths and Limitation of Qualitative and Quantitative Research Methods. European Journal of Education Studies, 3(9), 369-387.

Real, R. (2018). Is Porto safe? Retrieved March 19, 2019, from https://portoalities.com/en/porto-safe/.

Remoaldo, P., Ribeiro, J., Valeiro, L. and Santos, J. (2014). Tourists' perceptions of world heritage destinations: The case of Guimarães (Portugal). Tourism and Hospitality Research, 14(4), 206-218.

Saaty, T. (2008). Decision making with the analytic hierarchy process. International Journal of Services Sciences, 1(1), 83-98.

Saaty, T. (2013). Fundamentals of Decision Making and Priority Theory with the Analytic Hierarchy Process. Pittsburgh, PA: RWS Publications.

Santos C. A. (2004). Framing Portugal, representational dynamics. Annals of Tourism Research, 31(1), 122-138.

Santos, M. G. (2006). Espiritualidade, Turismo e Território - Estudo geográfico de Fátima. S. João do Estoril: Principia. 
Silva, R. (2018). Universidade do Porto bate recorde de estudantes internacionais. Retrieved March 15, 2019, from https://expresso.pt/sociedade/2018-02-20-Universidade-do-Portobate-recorde-de-estudantes-internacionais\#gs.1d4pff.

Silva, A., Fernão-Pires, M. and Bianchi-de-Aguiar, F. (2018). Portuguese vines and wines: heritage, quality symbol, tourism asset. Ciência e Técnica Vitivinícola, 33(1), 31-46.

Silva, J. and Silva, J. (2003). Inserção territorial das actividades turísticas em Portugal - uma tipologia de caracterização. Revista Portuguesa de Estudos Regionais, 1, 53-73.

Simková, E. and Holzner, J. (2014). Motivation of Tourism Participants. Procedia - Social and Behavioral Sciences, 159, 660-664.

Sormaz, U., Akmese, H., Gunes, E. and Aras, S. (2016). Gastronomy in Tourism. Procedia Economics and Finance, 39, 725-730.

Southan, J. (2018). The World's Friendliest Countries Revealed. Retrieved March 19, 2019, from https://www.forbes.com/sites/jennysouthan/2018/03/21/the-worlds-friendliestcountries-revealed/\#42f208e154ea.

Stojanov, S., Besermenji, S., Vujivic, M., Majstorovic, V. and Stojsavljevic, R. (2013). Measuring Tourism Potential of Places of Interest and Memorial Objects Using Analytical Hierarchy Process (AHP) - Case Study City Of Nis, Serbia. European Researcher, 59(9), 2306-2315.

Teixeira, M. and Romão J. (2013.). Turismo Religioso: uma alternativa económica para municípios do Seridó http://aplicativos.fipe.org.br/enaber/pdf/93.pdf.

Thanh, T. and Kirova, V. (2018). Wine tourism experience: A netnography study. Journal of Business Research, 83, 30-37.

Turismo de Portugal (2018). Registo Nacional de Agentes de Animação Turística. Lisboa: Turismo de Portugal.

Tutenges, S. (2012). Nightlife tourism: A mixed methods study of young tourists at an international nightlife resort. Tourist Studies, 12(2), 131-150.

UNESCO (2014). Historic Centre of Oporto, Luiz I Bridge and Monastery of Serra do Pilar. Available at: https://whc.unesco.org/en/list/755.

United Nations World Tourism Organization (UNWTO) (2011). Tourism Towards 2030: Global Overview. Madrid: UNWTO.

United Nations World Tourism Organization (UNWTO) (2017). UNWTO Annual Report 2016. Madrid: UNWTO.

Wong, M., Cheung, R. and Wan, C. (2013). A Study on Traveler Expectation, Motivation and Attitude. Contemporary Management Research, 9(2), 169-186.

World Economic Forum (WEF), (2017), The travel \& tourism competitiveness report 2017, World Economic Forum, Geneva, 370 p. Available at: https://www.wttc.org/economicimpact/country-analysis/country-reports/.

World Travel \& Tourism Council (WTTC), (2017), Travel \& tourism economic impact 2017 Portugal, World Travel \& Tourism Council, London, 19 p. Available at: https://www.wttc.org/economic-impact/country-analysis/country-reports/.

Yeoman, I. and McMahon-Beatle, U. (2016). The future of food tourism. Journal of Tourism Futures, 2(1), 95-98. 


\section{Author Biography}

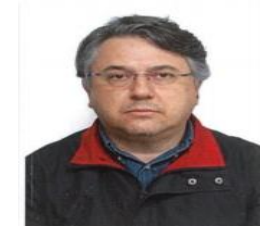

Oscar Silva has a PhD in Tourism Science from University of Perpignan (France) and ISCET (Portugal). He is a full professor at Higher Polytechnic Institute of Gaya (ISPGaya) and member of the Association of Tourism Professionals of Minho (APROTURM), with the position of President of the Supervisory Board. He is co-author of several publications involving touristic events in the city of Porto, such as Essência do Vinho, Serralves em Festa, Nós - Primavera Sound, and Marés Vivas. His current research areas include tourism policies, strategic planning in tourism, and evaluation of tourism projects.

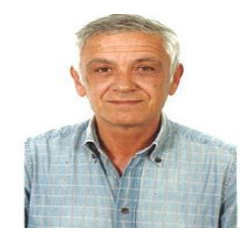

Nelson Amoedo has a MSc in Applied Maths from Faculty of Sciences of University of Porto (FCUP) and a BSc in Civil Engineering from Faculty of Engineering of University of Porto (FEUP). He has over 40 years of experience in the field of university education and experience as CEO in the commercial field over 10 years. His current research areas include applied statistics, mathematical modelling, support decision systems, and econometrics.

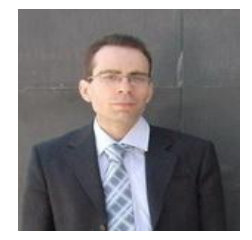

Fernando Almeida has a PhD. in Computer Science Engineering from Faculty of Engineering of University of Porto (FEUP). He also holds an MSc in Innovation and Entrepreneurship and an MSc in Informatics Engineering from FEUP. He has around 10 years of teaching experience at higher education levels in the field of computer science and management. He is currently a researcher at University of Porto and INESC TEC. His current research areas include innovation policies, entrepreneurship, software development, and decision support systems. 